DOI: https://doi.org/10.31073/abg.59.17

\title{
CHARACTERISTICS OF MILK FAT OF GREY UKRAINIAN CATTLE BREED
}

\author{
N. L. RIEZNYKOVA \\ Institute of Animal Breeding and Genetics nd. a. M.V.Zubets of NAAS (Chubynske, Ukraine) \\ https://orcid.org/0000-0002-6030-3463 - N. L. Rieznykova \\ Reznikovanatasha@ukr.net
}

Abstract. The peculiarities of fatty acid content of milk of Grey Ukrainian breed of breeding farm "Polyvanivka" and private farm "MotherFarm" is investigated. Fatty acid content was detected in the Ukrainian Laboratory of Quality and Food Safety in Agrarian Industry of the National University of Biological Resources and Nature of Ukraine, Kyjiv, at gas chromatograph Trace Ultra with FID detector and capillary column SP-2560 (Supelco). The results were compared to data of other scientists on fatty acid content of commercial breeds of Ukraine and previous own research on local Whiteheaded Ukrainian. There were detected noticeable individual deviations. Comparison of fatty acid content in the milk of investigated local breeds and commercial ones (holstenized Ukrainian Black-and-White breed and Holstein) showed similar content of saturated acids with certain fluctuations, but the quantity of essential $\alpha$-linoleic acid was 10 times lower in the milk of commercial breeds.

Keywords: Grey Ukrainian breed, cattle, gene pool conservation, milk fat, fatty acid content

\section{ОСОБЛИВОСТІ МОЛОЧНОГО ЖИРУ СІРОЇ УКРАЇНСЬКОЇ ПОРОДИ ВЕЛИКОЇ РОГАТОЇ ХУДОБИ}

\section{Н. Л. Рєзникова}

Інститут розведення і генетики тварин імені М.В.Зубия НААН (Чубинське, Украйна)

Досліджено особливості жсирнокислотного складу молока корів сірої української породи племзаводу «Поливанівка» та приватного підприємства "MotherFarm". Вміст жирних кислот визначали в Українській лабораторії очзінки якості та безпеки продукиії АПК НУБіП Украӥни за допомогою газового хроматографа Trace Ultra з полум'яно-іонізаційним детектором i капілярною колонкою SP-2560 (Supelco).

Результати порівнювали з даними інших авторів щзодо вмісту жирних кислот в молочі корів комериійних порід України та попередніми власними дослідженнями по білоголовій украӥнській породі. Виявлено помітні коливання вмісту окремих жирних кислот в межах вибірки. Порівняння вмісту жирних кислот в молочі локальних та комериійних порід засвідчує схожий кількісний склад насичених жирних кислот з певними коливаннями, проте кількість ессенціальної ліноленової кислоти була в 10 разів вищою в молочуі корів досліджених локальних nopid.

Ключові слова: сіра українська порода, велика рогата худоба, збереження генофонду, молочний жир, вміст жирних кислот

\section{ОСОБЕННОСТИ МОЛОЧНОГО ЖИРА СЕРОЙ УКРАИНСКОЙ ПОРОДЫ КРУПНОГО РОГАТОГО СКОТА}

\section{Н. Л. Резникова}

Институт разведения и генетики животных имени М.В.Зубиа НААН (Чубинское, Украина)

Исследованы особенности жирнокислотного состава молока коров серой украинской породы племзавода «Поливановка» и частного предприятия “MotherFarm". Содержание жирных кислот определяли в Украинской лаборатории оченки качества и безопасности про- 
дукиии АПК НУБиП Украины на газовом хроматографе Trace Ultra с пламенно-ионизационнымм детектором и капиллярной колонкой SP-2560 (Supelco). Результаты сравнивали с данными других авторов по содержанию жирных кислот в молоке коров коммерческих пород Украины и предылущими собственными исследованиями по белоголовой украинской породе. Выявлены заметные колебания содержания определенных жирных кислот в пределах выборки. Сравнение содержания жирных кислот в молоке локальных и коммерческих пород засвидетельствовало похожий количественный состав по насыщенным жирным кислотам с определенными колебаниями, хотя количество эссенциальной линоленовой кислоть было в 10 раз выше в молоке коров исследуемых локальных пород.

Ключевые слова: серая украинская порода, крупный рогатый скот, сохранение генофонда, молочный жир, содержание жирных кислот

Introduction. Grey Ukrainian cattle breed inseparably linked to the history of Ukraine and has great cultural value. This breed is one of ancient, which traces several millennia BC and the most unique cattle breed of Ukraine. Grey Ukrainian bulls are linked with ancient Ukrainian industrial international dealing - salt selling, which is witnessed to exist since 11 century [17]. Cattle of this breed were highly welcomed at markets of Russian empire $[14,16]$ because of strong and elastic skins (7\% of live weight $[5,11,13])$. And their live weight constituted up to $1300 \mathrm{~kg}$ [5]. Cows of the breed were characterized with good maternal qualities and fat milk (up to 9\%).

Since 1973 cows of the breed are not milked, but used as maternal base for this breed youngsters' rearing, as it was decided to breed it in beef direction.

But meat qualities of the breed significantly yield to meat qualities of the best international and national beef breeds of Ukraine. It caused the situation when Grey Ukrainian is going to be extinct as the main power of breed survive and prospering in market conditions is profit. Now this breed is available in two herds of Ukraine, counting about 1000 heads, conserved because of state policy in this direction (subordinated and leaded by institutions of National Academy of Agrarian Sciences of Ukraine), though at the beginning of XX century this breed numbered 2.8 million of heads. But press of market conditions since the beginning of $20^{\text {th }}$ century has led to the loss of some valuable traits of the breed, including specific cultural peculiarities (length of horns) and even disease resistance in certain cases. So, there is needed urgent measures for its conservation.

One of the possible ways of its conservation is commercialization of useful traits, which are superior to such traits of other breeds of Ukraine and the world. It is firstly qualitative traits of the breed, including content of milk.

One of the important constituents of taste and quality of milk is fat, which depends greatly on qualitative and quantitative fatty acid content. Besides that, saturated fatty acids, which constitute main part of milk fat are admitted to be facilitating thrombosis and aterosclorosis [30], because of cholesterol depositing. Vice versa, unsaturated acids take part in biosynthesis of prostaglandins [12], prevent heart diseasis [20,28], and diabetes [21], has antiatherogenic and antithrombogenic properties [19]. So, it was decided to investigate qualitative content of milk fat of Grey Ukrainian breed and find out its peculiarities.

Materials and methods. Milk for investigation was taken from the cows of Grey Ukrainian breed of state enterprize (research farm of the Institute of Grain of National Academy of Agrarian Sciences) and private farm of Kiev region, Bila Tserkva district ("MotherFarm"), where only one cow of the breed was milked. Cows were taken randomly, kept in one shed (in the frame of one farm) and fed the same ratio. Milk was taken after early milking. The detection of milk fatty acid content was carried out according to the state standard ISO 5508-2001 "Animal and Vegetable Fats and Oils. Analyzing of fatty acid methyl ethers by gas chromatography method". Preparation of samples was done in obedience to state standard ISO 5509-2002 "Animal and Vegetable Fats and Oils. Preparation of methyl ethers of fatty acids." Chromatographic analysis of fatty acids was carried out in the Ukrainian Laboratory of Quality and Food Safety in Agrarian Industry of the National University of Biological Resources and Nature of Ukraine, Kyjiv, at gas chromatograph Trace Ultra with FID detector and capillary column SP-2560 (Supelco). 
The specifics of research (investigation of milk of beef cattle), research price and availability of only one animal (at private farm), caused the volume of sample. The content of individual fatty acid was determined as a percentage of it to the total content of this class of organic compounds in the test sample. The error of the sample was calculated between two testing of the same sample. Mathematical processing of the data was done at the Excel software package. Comparative data on Whiteheaded Ukrainian was taken from own previous investigations [18], on other dairy breeds from literary sources $[1,7,8]$. Into the analysis, which represent the cumulative milk of the Grey Ukrainian, the milk of only one herd was included $(n=5)$, excluding milk of private farm animal. Data on Whiteheaded Ukrainian breed were interpolated on Grey Ukrainian acids quantity, as laboratory, where Whiteheaded Ukrainian milk was investigated, had wider panel for acid investigation.

Results and discussion. There was unified thought, that fatty acid content of milk is almost fully determined by feed consumed, but last research $[2,4,12]$ proves, that fatty acid content depends greatly on breed [9, 18], season [9], species [4, 19], keeping conditions [1, 2, 9] and stage of lactation $[9,12,21]$. Results of our investigation proves the latter. Cows of state breeding farm "Polyvanivka", which is situated in the southern east of Ukraine (Dnipropetrovska oblast) have similar content of fatty acids, as the cows of the same breed of private farm "MotherFarm", which is situated in the north of Ukraine (Kyjiv oblast) and cows of one farm have significant fluctuations inside the sample on the content of fatty acids (Table 1). So, it is possible to change fatty acid pattern in samples into more desirable, taking into account and combining not only feed, but breed, conditions and other factors for better and firm results.

Statistical processing of Grey Ukrainian breed sample and Whiteheaded Ukrainian breed sample showed, that in spite of being reared in different climatic zones and kept at different forms of ownership, which influenced, animals of the different breeds had mainly similar content of milk on fatty acids (Table 2). Milk of Grey Ukrainian breed contained less saturated acids $(66.61 \%)$, than milk of Whiteheaded Ukrainian $(68.37 \%)$ and, consequently, more unsaturated $(33.44 \%)$ against $31.17 \%$ of Whiteheaded Ukrainian. But the quantity of the most required in human organism essential acids (linoleic and $\alpha$-linoleic), which are not synthesized in organism, in the milk of Whiteheaded Ukrainian constitute $3.57 \%$, in the milk of Grey Ukrainian - 3.30\%. Alpha-linoleic ( $\omega$-3) acid is needed for heart and vessel health, stable emotional state, immunity, good state of skin (Danilova, 2018). But the interrelation of these two essential acids, which should be $2: 1-4: 1$, is in the required frame (3.7:1 in the milk of Whiteheaded Ukrainian and 3.65:1 - in the milk of Grey Ukrainian) in both breeds. Only being in such ratio, they protect vessels and heart from fat deposits, take out cholesterol and increase the number of lipids [6, 10, 26].

The higher total quantity of unsaturated acids in the milk of Grey Ukrainian breed is determined by richer content of monounsaturated fatty acids in it (30.14\% vs $27.60 \%)$. These acids (myristoleic, palmitoleic and oleic) are required for satisfactory work of organizm. Particularly, content of myristoliec acid is almost 5 times higher, than in the milk of Whiteheaded Ukrainian cattle $(\mathrm{p}<0,001)$. Palmitoleic acid content in the milk of Grey Ukrainian breed exceeds content of the acid in the milk of Whiteheaded more, than 7.5 times. The difference is highly significant $(\mathrm{td}=10,96$, $\mathrm{p}<0.001)$. Oleic $(\omega-9)$ acid is higher in the milk of Whiteheaded Ukrainian, but slightly. Oleic acid prevents cholesterol deposits in vessels $[15,27]$.

Content of short- and medium-chain saturated fatty acids (butyric, caproic, caprylic, capric, lauric) and long-chained stearic acid is higher, though mainly slightly, in the milk of Whiteheaded Ukrainian cattle. Milk of Grey Ukrainian cattle is "richer" in such saturated acids as palmitic, pentadeconic, myristic, margaric and arachidic. Arachidic acid is almost twice higher in the milk of Grey Ukrainian. Stearic acid is not fully admitted as "harmful" fatty acid, though it belongs to saturated acids. This acid is known to decrease the concentration of cholesterol in blood [25, 29], but as well can cause thrombosis. Butyric acid as well admitted to be useful for taste of product and human health, as it possesses cancer-preventive facilities $[20,22,23]$ and is specific for milk fat $[3$, $4,20]$. 
1. Fatty acid content in milk of Grey Ukrainian cattle

\begin{tabular}{|c|c|c|c|c|c|c|}
\hline \multirow{2}{*}{$\begin{array}{l}\text { Name and shorthand of } \\
\text { acids }\end{array}$} & \multicolumn{6}{|c|}{ Fatty acid content (\%) of milk of different cows } \\
\hline & \multicolumn{5}{|c|}{ State breeding farm «Polyvanivka» } & $\begin{array}{c}\text { Private farm } \\
\text { «MotherFarm» }\end{array}$ \\
\hline Butyric (C4:0) & $2.39 \pm 0.02$ & $2.37 \pm 0.02$ & $2.84 \pm 0.03$ & $2.23 \pm 0.02$ & $3.59 \pm 0.10$ & $3.17 \pm 0.08$ \\
\hline Caproic (C6:0) & $1.98 \pm 0.12$ & $2.53 \pm 0.09$ & $2.67 \pm 0.02$ & $2.70 \pm 0.04$ & $2.51 \pm 0.06$ & $2.03 \pm 0.02$ \\
\hline Caprylic (C8:0) & $1.19 \pm 0.08$ & $1.42 \pm 0.07$ & $1.71 \pm 0.06$ & $1.51 \pm 0.03$ & $1.46 \pm 0.02$ & $1.28 \pm 0.08$ \\
\hline Capric (C10:0) & $1.75 \pm 0.19$ & $2.61 \pm 0.08$ & $3.25 \pm 0.14$ & $2.88 \pm 0.08$ & $2.85 \pm 0.08$ & $2.39 \pm 0.01$ \\
\hline Lauric (C12:0) & $2.03 \pm 0.13$ & $2.69 \pm 0.09$ & $3.22 \pm 0.08$ & $3.21 \pm 0.01$ & $3.88 \pm 0.05$ & $2.39 \pm 0.01$ \\
\hline Myristic $(\mathrm{C} 14: 0)$ & $8.63 \pm 0.33$ & $9.59 \pm 0.05$ & $11.13 \pm 0.40$ & $13.03 \pm 0.12$ & $12.18 \pm 0.04$ & $10.19 \pm 0.05$ \\
\hline Myristoleic (C14:1) & $1.22 \pm 0.04$ & $1.39 \pm 0.06$ & $1.58 \pm 0.05$ & $1.49 \pm 0.01$ & $1.47 \pm 0.02$ & $0.63 \pm 0.01$ \\
\hline Pentadeconic (C15:0) & $2.17 \pm 0.01$ & $1.69 \pm 0.04$ & $1.46 \pm 0.06$ & $1.48 \pm 0.03$ & $1.57 \pm 0.10$ & $3.09 \pm 0.02$ \\
\hline Palmitic (C16:0) & $30.17 \pm 0.34$ & $27.29 \pm 0.25$ & $28.56 \pm 0.09$ & $31.80 \pm 0.04$ & $32.48 \pm 0.49$ & $26.36 \pm 0.06$ \\
\hline Palmitoleic (C16:1) & $1.45 \pm 0.05$ & $2.38 \pm 0.24$ & $2.14 \pm 0.04$ & $1.99 \pm 0.03$ & $1.90 \pm 0.03$ & $1.43 \pm 0.04$ \\
\hline Margaric $(\mathrm{C} 17: 0)$ & $1.02 \pm 0.05$ & $0.89 \pm 0.02$ & $0.82 \pm 0.01$ & $0.77 \pm 0.04$ & $0.95 \pm 0.02$ & $1.92 \pm 0.06$ \\
\hline Stearic (C18:0) & $10.60 \pm 0.23$ & $12.06 \pm 0.05$ & $10.43 \pm 0.55$ & $9.03 \pm 0.06$ & $9.81 \pm 0.07$ & $9.24 \pm 0.18$ \\
\hline Oleic (C18:1н9c) & $31.55 \pm 0.76$ & $29.29 \pm 0.25$ & $26.53 \pm 0.26$ & $24.30 \pm 0.28$ & $22.04 \pm 0.26$ & $31.07 \pm 0.46$ \\
\hline Linoleic (C18:2н6c) & $2.93 \pm 0.02$ & $2.81 \pm 0.02$ & $2.59 \pm 0.07$ & $2.39 \pm 0.04$ & $2.21 \pm 0.05$ & $3.14 \pm 0.24$ \\
\hline$\alpha$-linoleic $\left(\mathrm{C} 18: 3_{\mathrm{H} 3}\right)$ & $0.56 \pm 0.04$ & $0.67 \pm 0.01$ & $0.71 \pm 0.01$ & $0.82 \pm 0.02$ & $0.81 \pm 0.01$ & $1.48 \pm 0.06$ \\
\hline Arachidic (C20:0) & $0.30 \pm 0.01$ & $0.28 \pm 0.01$ & $0.30 \pm 0.01$ & $0.30 \pm 0.03$ & $0.26 \pm 0.02$ & $0.15 \pm 0.01$ \\
\hline Behenic (C22:0) & $0.11 \pm 0.01$ & $0.11 \pm 0.01$ & $0.10 \pm 0.01$ & $0.10 \pm 0.01$ & $0.07 \pm 0.01$ & $0.08 \pm 0.01$ \\
\hline
\end{tabular}

2. Fatty acid content of milk of Grey Ukrainian and Whiteheaded Ukrainian cattle

\begin{tabular}{|c|c|c|c|c|c|c|}
\hline \multirow{3}{*}{$\begin{array}{l}\text { Name and shorthand of } \\
\text { acids }\end{array}$} & \multicolumn{6}{|c|}{ Fatty acid content of different breeds } \\
\hline & \multicolumn{3}{|c|}{$\begin{array}{c}\text { Grey Ukrainian cattle of «Polyvanivka» } \\
\text { state breeding farm }(\mathrm{n}=5)\end{array}$} & \multicolumn{3}{|c|}{$\begin{array}{l}\text { Whiteheaded Ukrainian cattle } \\
\text { (Rieznykova, 2016) }(\mathrm{n}=4)\end{array}$} \\
\hline & $\mathrm{M} \pm \mathrm{m}$ & S.D. & C.V. & $\mathrm{M} \pm \mathrm{m}$ & S.D. & C.V. \\
\hline Butyric (C4:0) & $2.68 \pm 0.249$ & 0.56 & 0.21 & $5.33 \pm 0.561$ & 1.12 & 0.21 \\
\hline Caproic (C6:0) & $2.48 \pm 0.130$ & 0.29 & 0.12 & $3.03 \pm 0.263$ & 0.53 & 0.17 \\
\hline Caprylic (C8:0) & $1.46 \pm 0.084$ & 0.19 & 0.13 & $1.62 \pm 0.158$ & 0.32 & 0.20 \\
\hline Capric (C10:0) & $2.67 \pm 0.251$ & 0.56 & 0.21 & $3.11 \pm 0.326$ & 0.65 & 0.21 \\
\hline Lauric $(\mathrm{C} 12: 0)$ & $3.01 \pm 0.309$ & 0.69 & 0.23 & $3.34 \pm 0.293$ & 0.59 & 0.18 \\
\hline Myristic $(\mathrm{C} 14: 0)$ & $10.91 \pm 0.809$ & 1.81 & 0.17 & $10.5 \pm 0.406$ & 0.81 & 0.08 \\
\hline Myristoleic (C14:1) & $1.43 \pm 0.061$ & 0.14 & 0.09 & $0.29 \pm 0.033$ & 0.07 & 0.23 \\
\hline Pentadeconic (C15:0) & $1.67 \pm 0.130$ & 0.29 & 0.17 & $1.53 \pm 0.159$ & 0.32 & 0.21 \\
\hline Palmitic (C16:0) & $30.06 \pm 0.970$ & 2.17 & 0.07 & $27.29 \pm 1.575$ & 3.15 & 0.12 \\
\hline Palmitoleic (C16:1) & $1.97 \pm 0.154$ & 0.34 & 0.17 & $0.26 \pm 0.027$ & 0.05 & 0.21 \\
\hline Margaric $(\mathrm{C} 17: 0)$ & $0.89 \pm 0.045$ & 0.10 & 0.11 & $0.80 \pm 0.077$ & 0.15 & 0.19 \\
\hline Stearic (C18:0) & $10.39 \pm 0.501$ & 1.12 & 0.11 & $12.09 \pm 1.151$ & 2.30 & 0.19 \\
\hline Oleic $(\mathrm{C} 18: 1 \mathrm{H} 9 \mathrm{c})$ & $26.74 \pm 1.699$ & 3.80 & 0.14 & $27.05 \pm 0.718$ & 1.44 & 0.05 \\
\hline Linoleic (C18:2н6с) & $2.59 \pm 0.132$ & 0.30 & 0.11 & $2.81 \pm 0.273$ & 1.55 & 0.19 \\
\hline$\alpha$-linoleic $(\mathrm{C} 18: 3 \mathrm{H} 3)$ & $0.71 \pm 0.048$ & 0.11 & 0.15 & $0.76 \pm 0.115$ & 0.23 & 0.30 \\
\hline Arachidic (C20:0) & $0.29 \pm 0.008$ & 0.02 & 0.06 & $0.18 \pm 0.008$ & 0.02 & 0.08 \\
\hline Behenic (C22:0) & $0.10 \pm 0.007$ & 0.02 & 0.17 & & & \\
\hline
\end{tabular}

Comparison of fatty acid content in milk of local, which are both above-presented breeds and commercial ones (holstenized Ukrainian Black-and-White breed and Holstein) $[1,7,8]$ showed similar content of saturated acids with certain fluctuations, but the quantity of essential $\alpha$-linoleic acid was 10 times lower in the milk of commercial breeds [1], than in the milk of both above-mentioned local breeds. So, content of potentially non-desired saturated caproic (2.71), caprylic (1.70), lauric (4.11), myristic (11.68) acids was higher in the milk of holstenized breed [1]. Content of unsaturated myristoleic (0.93), pamitoleic (1.21) and oleic (22.14) acids in the milk of commercial breeds [1] are lower, than in the milk of Grey Ukrainian breed. Some saturated acids' content in the milk of commercial breeds are lower, than in the milk of investigated local, particularly palmitic (29.23), margaric (0.53) and stearic (10.27) [1]. In other research on black-and-white cattle [7], content of saturated stearic acid exceeds such in the milk of Grey Ukrainian by 3\% (13.96), content of other saturated acid - margaric almost twice exceeds its content in the milk of both investigated local breeds (Grey Ukrainian and Ukrainian Whiteheaded) - 1.60\% [7]. Palmitic acid (30.76\%) and pentadeconic acid $(1.68 \%)$, both of which are «harmful» $[7,18,20]$ saturated, content in the milk of black-and- 
white cattle [7] exceeds such of both local investigated breeds (Table 2). Content of polyunsaturated linoleic acid in the milk of black-and-white cattle is lower, than in the milk of both investigated local breeds (Grey Ukrainian and Ukrainian Whiteheaded) and compose 2.36\%. Though content of $\omega-9$ oleic acid is higher in the milk of black-and-white cattle (35.02\%).

Conclusions. 1. Milk fatty acid content deviates more significantly in the frame of one farm, than between cows of different farms.

2. Milk of the investigated cows of Grey Ukrainian cattle is characterized with $66.61 \%$ saturated and consequently, $33.44 \%$ unsaturated fatty acids. Milk of the cattle constitute $30.14 \%$ of monousaturated fatty acids.

3. Quantity of essential linoleic and $\alpha$-linoleic fatty acids in the milk of Grey Ukrainian cattle constitutes $3.30 \%$.

4. Interrelation of $\omega-3$ to $\omega-6$ acid in the milk of Grey Ukrainian cattle is 1:3.65.

5. Comparison of fatty acid content in the milk of Grey Ukrainian and Whiteheaded Ukrainian breeds, which are local, and commercial ones (holstenized Ukrainian Black-and-White breed and Holstein) showed similar content of saturated acids with certain fluctuations, but the quantity of essential $\alpha$-linoleic acid was 10 times lower in the milk of commercial breeds, than in the milk of both above-mentioned local breeds.

Acknowledgements. Special acknowledgement should be given to professor Yu. P. Polupan for methodical directions and advice during the experiment. Great acknowledgement is given to Polyvanivka state farm team and especially to veterinarian V. Donets for the facilitating sampling.

\section{BIBLIOGRAPHY}

1. Бергілевич, О. М. Аналіз жирнокислотного складу сирого молока, отриманого за сучасних технологій доїння / О. М. Бергілевич, А. М. Марченко // Вісник Сумського національного аграрного університету. Серія : "Ветеринарна медицина". - 2014. - Вип. 6. - С. 89-93.

2. Бурда, Л. Р. Жирнокислотний склад молока овець української гірськокарпатської породи при випасанні на полонинних та низинних пасовищах / Л. Р. Бурда // Біологія тварин. - Львів, 2009. - T. 11, № 1-2. - С. 155-160.

3. Вміст біологічно активних жирних кислот у вершковому маслі, виробленому в Україні / Р. А. Голубець, О. В. Голубець, С. М. Шкаруба, О. І. Віщур // Біологія тварин. - Львів, 2011. T. 13, № 1-2. - С. 77-86.

4. Галух, Б. І. Особливості жирнокислотного складу бринзи, виготовленої з молока різних видів тварин / Б. І. Галух // Науково-технічний бюлетень Інституту біології тварин НААН. Львів, 2010. - Т. 11, № 2-3. - С. 11-30.

5. Государственная племенная книга крупного рогатого скота серой украинской породы. T. IV. - Киев-Харьков : Госиздат с.-х. лит. УССР, 1950. - 151 с.

6. Данілова, I. С. Вміст жирних кислот у м'ясі різних видів равликів / I. С. Данілова // Вісник Полтавської державної аграрної академії. - 2018. - № 4. - С. 168-173.

7. Жирнокислотний склад загальних ліпідів молозива та молока корів / М. Д. Камбур, А. А. Замазій, С. М. Лівощенко, О. С. Передера // Вісник Сумського національного аграрного університету. Серія : "Ветеринарна медицина". - 2012. - Вип. 7. - С. 27-29.

8. Жирнокислотний склад ліпідів молока корів за різного вмісту органічного і неорганічного селену в раціоні / Н. В. Голова, О. В. Голубець, А. П. Дідович, І. В. Вудмаска // Науковий вісник Львівського національного університету ветеринарної медицини та біотехнологій ім. Гжицького. - 2011. - Т. 13, № 4 (3). - С. 66-71.

9. Копке, Г. Жирные кислоты в молоке: что они нам говорят о корове? / Грит Копке, Герман Свалве ; Отделение разведения Институт аграрных и пищевых наук, университет Мартина Лютера ; перевод Елены Бабенко, специально для soft-agro.com. - URL: https://softagro.com/korovy/zhirnye-kisloty-v-moloke-chto-oni-nam-govoryat-o-korove.html

10. Ігнатовська, М.В.Жирнокислотний склад м'язової тканини кролів під впливом вітаміну Е / М. В. Ігнатовська // Тваринництво України. - 2014. - № 5. - С. 40-43. 
11. Каллестинов, Д. К. Породы крупного рогатого скота / Д. К. Каллестинов // Издание А. Ф. Девриена. - СПб., 1914. - 47 с.

12. Камбур, М. Д. Жирнокислотний склад молозива та молока свиноматок різних типів вищої нервової діяльності / М. Д. Камбур, А. А. Замазій, А. В. Піхтірьова // Вісник Сумського національного аграрного університету. Серія : "Ветеринарна медицина". - 2012. - Вип. 1. C. 25-28.

13. Классен, Х. Породи великої рогатої худоби на Україні / Х. Классен, А. Соловйов. - Харків : Держсільгоспвидав, 1934. - 175 с.

14. Кулешовъ, П. Н. Къ альбому породъ крупного рогатого скота, разводимого въ Россіи / П. Н. Кулешовъ. - СПб., 1897. - 34 с.

15. Олеиновая кислота. Описание. [Электронный ресурс] - Режим доступа : https://4fresh.ru/glossary/oleic-acid

16. Придорогин, М. И. Крупный рогатый скот (важнђйшія породы) / М. И. Придорогин. СПб : Изд. П. П. Сойкина, 1912. - 175 с.

17. Проскурова, С. В. Чумацтво // Енциклопедія історії України: Т. 10: Т-Я / редкол. : В. А. Смолій (голова) та ін. ; НАН України, Інститут історії України. - К. : Наукова думка, 2013. -688 c.

18. Рєзникова, Н. Л. Особливості якісного складу молока корів білоголової української породи / Н. Л. Рєзникова // Розведення і генетика тварин. - К., 2016. - Вип. 51. - С. 290-295. DOI: https://doi.org/10.31073/abg.51.39

19. Стапай, П. В. Особливості хімічного складу і біологічної цінності молока овець / П. В. Стапай, Л. Р. Бурда // Біологія тварин. - Львів, 2010. - Т. 12, № 1. - С. 44-53.

20. Цісарик, О. Й. Жирнокислотний склад молочного жиру корів / О. Й. Цісарик, Г. В. Дроник // Біологія тварин. - Львів, 2008. - Т. 10, № 1-2. - С. 84-102.

21. Цюпко, В. В. Склад молочного жиру корів у різні строки після отелення / В. В. Цюпко // Вісник Дніпропетровського університету. Серія : «Біологія. Екологія». - 2010. - Вип. 18, т. 2. - С. 119-122.

22. Belobrajdic, D. P. Dietary butyrate inhibits NMU-induced mammary cancer in rats / D. P. Belobrajdic, G. H. Mcintosh // Nutrition and Cancer. - 2000. - Vol. 36, No. 2. - P. 217-223.

23. Brouns, F. Resistant starch and "the butyrate revolution" / F. Brouns, B. Kettlitz, E. Arrigoni // Trends in Food Science and Technology. - 2002. - Vol. 13, No. 8. - P. 251-261.

24. Fatty Acids, Common Names, and Abbreviations. Download Table [online] https://www.researchgate.net/figure/Fatty-Acids-Common-Names-and-Abbreviations_tbl1_267714030

25. Grundy, S. M. What is the desirable ratio of saturated, polyunsaturated, and monounsaturated fatty acids in the diet? / S. M. Grundy // Am. J. Clin. Nutr. - 1997. - Vol. 66. - P. 988-990.

26. What is the optimum $\omega-3$ to $\omega-6$ fatty acid (FA) ratio of parenteral lipid emulsions in postoperative trauma? / B. J. Morlion, E. Torwesten, K. Wrenger, C. Puchstein, P. Furst // Clinical Nutrition. - 1997. - Vol. 16, suppl. 2. - P. 49.

27. Oleic acid is a potent inhibitor of fatty acid and cholesterol synthesis in C6 glioma cells / F. Natali, L. Siculella, S. Salvati, G. V. Gnoni // Journal of Lipid Research. - 2007. - Vol. 48, no. 9. - P. 1966-1975.

28. Okuyama, H. High $n-6$ to $n-3$ ratio of dietary fatty acids rather than serum cholesterol as a major risk factor for coronary heart disease / H. Okuyama // European Journal of Lipid Science and Technology. - 2001. - Vol. 103. - P. 418-422.

29. Parodi, P. W. Nutritional significance of milk lipids / P. W. Parodi // Advanced Dairy Chemistry. - 2006. - Vol. 2. - P. 601-639.

30. Ulbricht, T. L. V. Coronary Heart Disease: Seven Dietary Factors / T. L. V. Ulbricht, D. A. T. Southgate // The Lancet. - 1991. - Vol. 338, Issue 8773. - P. 985-992. Mode of access: http://dx.doi.org/10.1016/0140-6736(91)91846-M. 


\section{REFERENCES}

1. Berhilevych, O. M., and A. M. Marchenko. 2014. Analiz zhyrnokyslotnoho skladu syroho moloka, otrymanoho za suchasnykh tekhnolohiy doyinnya - Analysis of fatty acid raw milk content, obtained at modern technologies of milking. Visnyk Sums'koho natsional'noho ahrarnoho universytetu. Ser. "Veterynarna medytsyna" - Digest of Sumy National Agrarian University. 6:89-93 (in Ukrainian).

2. Burda, L. R. 2009. Zhyrnokyslotnyy sklad moloka ovets' ukrayins'koyi hirs'kokarpat·s'koyi porody pry vypasanni na polonynnykh ta nyzynnykh pasovyshchakh - Fatty acid content of milk of Ukrainian Girskokarpatska sheep, when pastured at highland meadows and lowland pastures. Biolohiya tvaryn - Animal biology. 11(1-2):156-161 (in Ukrainian).

3. Holubets', R. A., O. V. Holubets', S. M. Shkaruba, and O. I. Vishchur. 2011. Vmist biolohichno aktyvnykh zhyrnykh kyslot u vershkovomu masli, vyroblenomu v Ukrayini - Content of biologically active fatty acids in butter, manufactured in Ukraine. Biolohiya tvaryn - Animal biology. 13(1-2):77-86 (in Ukrainian).

4. Halukh, B. I. 2010. Osoblyvosti zhyrnokyslotnoho skladu brynzy, vyhotovlenoyi z moloka riznykh vydiv tvaryn - Peculiarities of fatty acid content of brined soft cheese bryndza, made of milk of different animal species. Naukovo-tekhnichnyy byuleten' Instytutu biolohiyi tvaryn - Scientifictechnical bulletin of Institute of Animal Biology. 11(2-3):11-30 (in Ukrainian).

5. Gosudarstvennaja plemennaja kniga krupnogo rogatogo skota seroj ukrainskoj porody. Tom IV - Herdbook of Grey Ukrainian cattle. Vol. IV. 1950. Kiev-Har'kov : Gosizdat s.-h. lit. USSR (in Ukrainian).

6. Danilova, I. S. 2018. Vmist zhyrnykh kyslot u m"yasi riznykh vydiv ravlykiv - Fatty acid content of snails' species meat. Visnyk Poltavs'koyi derzhavnoyi ahrarnoyi akademiyi-Digest of Poltava State Agrarian Academy. 4:168-173 (in Ukrainian).

7. Kambur, M. D., A. A. Zamaziy, Ye. M. Livoshchenko, and O. S. Peredera. 2012. Zhyrnokyslotnyy sklad zahal'nykh lipidiv molozyva ta moloka koriv - Fatty acid content of general colostrum and milk lipids. Visnyk Sums'koho natsional'noho ahrarnoho universytetu. Ser. "Veterynarna medytsyna" - Digest of Sumy National Agrarian University. Veterinary medicine. 7:27-29 (in Ukrainian).

8. Golova, N. V., O. V. Holubets', A. P. Didovych, and I. V. Vudmaska. 2011. Zhyrnokyslotnyy sklad lipidiv moloka koriv za riznoho vmistu orhanichnoho i neorhanichnoho selenu v ratsioni - Fatty acid composition of cows' milk lipids at different content of organic and non-organic selenium in ration. Naukovyy visnyk L'vivs'koho natsional'noho universytetu veterynarnoyi medytsyny ta biotekhnolohiy im. Gzhyts'koho - Scientific digest of Stepan Gzhytskiy Lviv National University. 13(4(3):66-71 (in Ukrainian).

9. Zhirnye kisloty v moloke: chto oni nam govorjat o korove? - Fatty acids in milk: what do they tell about? [online] URL: https://soft-agro.com/korovy/zhirnye-kisloty-v-moloke-chto-oni-nam-govoryat-o-korove.html

10. Ihnatovs'ka, M. V. 2014. Zhyrnokyslotnyy sklad m"yazovoyi tkanyny kroliv pid vplyvom vitaminu E - Fatty acid content of rabbits' muscle tissue under the influence of E vitamin in micellar carrier. Tvarynnytstvo Ukrayiny - Animal breeding of Ukraine. 5:40-43 (in Ukrainian).

11. Kallestinov, D. K. 1914. Porody krupnogo rogatogo skota-Cattle breeds. Saint-Petersbugh, A. F. Devrien publishing (in Russian).

12. Kambur, M. D., A. A. Zamaziy, and A. V. Pikhtir'ova. 2012. Zhyrnokyslotnyy sklad molozyva ta moloka svynomatok riznykh typiv vyshchoyi nervovoyi diyal'nosti - Fatty acid content of colostrum and milk of pig dams of different types of higher nervous activity. Visnyk Sums'koho natsional'noho ahrarnoho universytetu. Ser. "Veterynarna medytsyna" - Digest of Sumy National Agrarian University. Veterinary medicine. 1:25-28 (in Ukrainian).

13. Klassen, X., and A. Solovyov. 1934. Porody velykoyi rohatoyi khudoby na Ukrayini - Cattle breeds in Ukraine. Kharkiv : Derzhsil'hospvydav (in Ukrainian). 
14. Kuleshov, P. N. 1897. K al'bomu porod krupnogo rogatogo skota, razvodimogo v Rossii. - To the album of breeds, bred in Russia. Saint-Petersburg (in Russia).

15. Oleinovaja kislota. Opisanie - Oleic acid. Description. [online] https://4fresh.ru/glossary/oleic-acid (Accessed 18.02.2020).

16. Pridorogin, M. I. 1912. Krupnyj rogatyj skot (vazhnrojshija porody) - Cattle (the most important breeds). Saint-Petersburg (in Russia).

17. Proskurova, S. V. 2013. Chumatstvo. Entsyklopediya istoriyi Ukrayiny : T. 10: T-Ya-Chumatstvo. Encyclopedia of history of Ukraine. Kyyiv, Naukova dumka, 688 (in Ukrainian).

18. Ryeznykova, N. L. 2016. Osoblyvosti yakisnoho skladu moloka koriv biloholovoyi ukrayins'koyi porody - The peculiarities of qualitative content of Ukrainian Whiteheaded cows' milk. Rozvedennya $i$ henetyka tvaryn - Animal Breeding and Genetics digest. 51:290-295 DOI: https://doi.org/10.31073/abg.51.39 (in Ukrainian).

19. Stapay, P. V., and L. R. Burda. 2010. Osoblyvosti khimichnoho skladu i biolohichnoyi tsinnosti moloka ovets' - Features of chemical content and biological value of sheep milk. Biolohiya tvaryn - Animal biology. 12(1):44-53 (in Ukrainian).

20. Tsisaryk, O. Y., and H. V. Dronyk. 2008. Zhyrnokyslotnyy sklad molochnoho zhyru koriv Fatty acid composition of cow milk fat. Biolohiya tvaryn - Animal biology. 10(1-2):84-102 (in Ukrainian).

21. Tsyupko, V. V. 2010. Sklad molochnoho zhyru koriv u rizni stroky pislya otelennya - Cows' fatty acid content at different terms after calving. Visnyk Dnipropetrovs'koho universytetu. Ser. «Biolohiya. Ekolohiya»-Digest of Dnipropetrovsk University. Biology. Ecology. 18 (2):119-122 (in Ukrainian).

22. Belobrajdic, D. P., and G. H. Mcintosh. 2000. Dietary butyrate inhibits NMU-induced mammary cancer in rats. Nutrition and Cancer. 36(2):217-223 (in English).

23. Brouns, F., B. Kettlitz, and E. Arrigoni. 2002. Resistant starch and "the butyrate revolution". Trends in Food Science and Technology. 13(8):251-261 (in English).

24. Fatty Acids, Common Names, and Abbreviations. Download Table [online] https://www.researchgate.net/figure/Fatty-Acids-Common-Names-and-Abbreviations_tbl1_267714030 (in English).

25. Grundy, S. M. 1997. What is the desirable ratio of saturated, polyunsaturated, and monounsaturated fatty acids in the diet? Am. J. Clin. Nutr. 66:988-990 (in English).

26. Morlion, B. J., E. Torwesten, K. Wrenger, C. Puchstein, and P. Furst. 1997. 'What is the optimum $\omega-3$ to $\omega-6$ fatty acid (FA) ratio of parenteral lipid emulsions in postoperative trauma? Clinical Nutrition. 16(2):49 (in English).

27. Natali, F., L. Siculella, S. Salvati, and G. V. Gnoni. 2007. Oleic acid is a potent inhibitor of fatty acid and cholesterol synthesis in C6 glioma cells. Journal of Lipid Research. 48(9):1966-1975 (in English).

28. Okuyama, H. 2001. High n-6 to n-3 ratio of dietary fatty acids rather than serum cholesterol as a major risk factor for coronary heart disease. European Journal of Lipid Science and Technology. 103:418-422 (in English).

29. Parodi, P. W. 2006. Nutritional significance of milk lipids. Advanced Dairy Chemistry. 2:601-639 (in English).

30. Ulbricht, T. L. V., and D. A. T. Southgate. 1991. Coronary Heart Disease: Seven Dietary Factors'. The Lancet. 338(8773):985-992. Mode of access: http://dx.doi.org/10.1016/01406736(91)91846-M (in English).

Одержано редколегією 10.04.2020 p.

Прийнято до друку 24.04.2020 p. 